\title{
PENDIDIKAN MULTIKULTURAL DALAM KEARIFAN LOKAL SUKU DONGGO BIMA
}

\author{
Ihlas dan Kaharuddin \\ Isntitut Agama Islam (IAI) Muhammadiyah Bima \\ Email: ihlas-ihlashasan14@gamil.com \\ kaharazzam@gmail.com
}

\begin{abstract}
Abstrak
Artikel ini membahas tentang pendidikan multikultural dalam kearifan lokal suku donggo bima. Pemahaman pendidikan multikultural merupakan sebuah upaya dalam meredam potensi konflik dan mewujudkan kerukukan sosial, masyarakat Nggeru Kopa Desa Palama Kecamatan Donggo Kabupaten Bima sejak puluhan tahun silam hingga sekarang tetap merawat kearifan lokalnya. Kearifan lokal didaerah tersebut ternyata dipandang efektif sebagai media komunikasi dan resolusi konflik bagi masyarakat setempat. Pada penelitian ini, menggunakan pendekatan Etnografi. Pendekatan etnografi merupakan pekerjaan mendeskripsikan suatu kebudayaan. Tujuan utama aktivitas ini adalah untuk memahami suatu kultur masyarakat setempat. Riset ini dilakukan di Dusun Nggeru Kopa Desa Palama Kecamatan Donggo Kabupaten Bima. Teknik Pengumpulan Data dalam penelitian ini adalah observasi, wawancara, dokumentasi, tekhnik mencatat dan tekhnik rekaman. Sedangkan analisis data dalam penelitian ini adalah kualitatif, yang terdiri dari tiga komponen pokok yaitu pengumpulan data, reduksi data, sajian data, dan penarikan simpulan dan verifikasi. Adapun hasil temuan dalam penelitian ini adalah Pertama, kearifan lokal yang ada Suku Donggo Kabupaten Bima meliputi cepe kanefe, doa jama, tio riana atau cama, perkawinan silang dan tradisi nikah sesama keluarga sendiri dan pantang menikah orang luar. Sederet kearifan lokal tersebut merupakan khasanah kolekasi budaya yang dimiliki oleh masyarakat tersebut, kedua, Kearifan lokal yang dimiliki oleh masyarakat Donggo merupakan aspek yang paling berperan dalam mewujudkan kerukunan ummat beragama pada masyarakat di dusun Nggeru Kopa desa Palama Kabupaten Bima.

Kata Kunci: Multikultural, Kearifan Lokal, Suku Donggo
\end{abstract}

\section{PENDAHULUAN}

eragaman dan perbedaan merupakan desain Tuhan
(sunatullah) yang tidak dapat dielakkan dari panggung
kehidupan, condition sine quo non (Ahmad Ansori, 2007). Pepatah Arab menyebutnya sebagai min nazawin al-hayah (keniscayaan hidup). Kehadirannya akan senantiasa mutlak. Kendati demikian, 
ternyata nilai-nilai pluralitas dan multikulturalitas kurang cukup diapresiasi oleh kebanyakan orang. Ini dibuktikan dengan masih banyaknya individu dan kelompok tertentu yang ingin meniadakan kebhinekaan, menggantinya dengan ketunggalan dan keseragaman (univormity).

Indonesia, melebihi kebanyakan negara-negara lain, merupakan negara yang tidak saja multi-suku, multi-etnik, multi-agama tetapi juga multi-budaya. Kemajemukan tersebut pada satu sisi merupakan kekuatan sosial dan keragaman yang indah apabila satu sama lain bersinergi dan saling bekerja sama untuk membangun bangsa. Namun, pada sisi lain, kemajemukan tersebut apabila tidak dikelola dan dibina dengan tepat dan baik akan menjadi pemicu dan penyulut konflik dan kekerasan yang dapat menggoyahkan sendi-sendi kehidupan berbangsa (Martin Van Bruinessen, 2002).

Berbagai prasangka sosial dalam masyarakat majemuk tidak bersifat statis, tetapi dinamis. Ia dapat berubah-ubah seiring dengan berjalannya proses interaksi sosial suatu masyarakat. Ia dapat menuju interaksi sosial yang lebih baik ataupun lebih buruk. Dalam kurun waktu tertentu, golongan-golongan penduduk bisa menjadi lebih saling mencurigai, saling membenci, tetapi juga bisa menjadi saling memahami dan saling menghormati (Hairus Salim dan Suhadi, 2007).

Perbedaan suku dan keyakinan (religion) sering menjadi pemicu konfilk yang terjadi belakangan ini. Hingga meruntuhkan kimia sosial yang telah mapan (Sudarwan Danim). Dalam kondisi seperti ini, kehadiran lembaga pendidikan kadang tidak memberi makna bagi kerukungan suatu komunitas sosial. Bahkan pendidikan dianggap 'tumpul' dalam melerai masalah yang menggejala dalam kehidupan masyarakat dewasa ini.

Ditengah kondisi sosial yang demikian, perlu kiranya menggali kembali potensi keraifan lokal sebagai jembatan penyatu perbedaan antar komunitas sosial. Maka tugas kita sekarang ialah menemukan kearifan lokal dan memfungsikannya untuk mengembangkan kehidupan masyarakat yang berkeadaban. Secara sederhana dapat dikatakan bahwa kehidupan masyarakat semacam itu, dalam bahasa rakyat Indonesia, 
adalah kehidupan yang sejahtera lahir dan batin dan berada bi bawah naungan keampunan Allah (wa rabb ghafur); juga masyarakat yang diberkahi oleh Allah (barakat min al-sama' wa al-ardl); masyarakat yang aman damai (aminan muthma'innan). Masyarakat seperti itu tidak akan lahir secara tiba-tiba, tetapi dari proses yang melibatkan usaha manusia, yang salah satunya ialah pertimbangan terhadap pentingnya kearifan lokal.

Kearifan lokal (local wisdom) akhir-akhir ini menjadi subyek perbincangan yang semakin ramai di berbagai kalangan karena posisinya yang sangat penting dalam kehidupan masyarakat. Ia merupakan perwujudan dari nilai lokal (local value) yang dipandang positif karena fungsinya dalam menjamin harmoni dan solidaritas sosial serta dipandang efektif dalam transformasi sosial.

Kearifan lokal tentu saja harus digali dalam maknanya yang paling substansial dari tradisi lokal (local tradition) dan kemudian secara selektif ditarik ke dalam nilai-nilai keadaban. Dengan kata lain, tidak semua tradisi lokal mengandung nilai keadaban, dan karena itu tidak semua tradisi lokal menjadi sumber bagi kearifan lokal. Bagi kita, tradisi lokal harus terseleksi untuk ditransformasikan ke dalam kearifan lokal dan harus paralel dengan nilai-nilai ajaran Islam yang telah menjadi worldview (pandangan dunia) bagi setiap Muslim (Ahmad Ansori, 2007).

Dalam rangka meredam potensi konflik dan mewujudkan kerukukan sosial, masyarakat Nggeru Kopa Desa Palama Kecamatan Donggo Kabupaten Bima sejak puluhan tahun silam hingga sekarang tetap merawat kearifan lokalnya. Kearifan lokal didaerah tersebut ternyata dipandang efektif sebagai media komunikasi dan resolusi konflik bagi masyarakat setempat. Sebab di desa tersebut memiliki tiga kepercayaan; Islam, Katolik dan Protestan.

Kearifan lokal yang ada juga terbukti menciptakan harmoni sosial sekaligus menjadi media integrasi antar ummat beragama di desa tersebut. Hal itu dapat dilihat dari keakraban dan silaturahmi antar keluarga dan tetangga yang beda agama berjalan damai. Menariknya, tradisi gotong royong suku Donggo yang ada di Nggeru Kopa tetap 
dilakukan, dan makin ditumbuh suburkan. Bahkan pembangunan Mesjid dan Gereja juga dilakukan secara bersama-sama.

Lebih dari itu, tidak sedikit terjadi perkawinan silang antaragama tanpa mempermasalahkan keyakinan satu sama lain. Sejauh ini kondisi sosial masyarakat setempat masih dalam bingkai yang rukun. Untuk itulah peneliti memiliki ketertarikan yang cukup mendalam untuk melakukan riset di desa tersebut guna menggali lebih dalam terkait potensi kearifan lokal yang ada di desa tersebut.

\section{TINJAUAN TEORI}

\section{Tradisi dan Kearifan Lokal}

Tradisi (Bahasa Latin: traditio, "diteruskan") atau kebiasaan, dalam pengertian yang paling sederhana adalah sesuatu yang telah dilkukan untuk sejak lama dan menjadi bagian dari kehidupam suatu kelompok masyarakat, biasanya dari suatu negara, kebudayaan, waktu, atau agama yang sama. Hal yang paling mendasar dari tradisi adalah informasi yang diteruskan dari generasi ke generasi baik tertulis maupun lisan, karena tanpa adanya ini, suatu tradisi dapat punah (Amirullah Syarbini, 2011).

Dari uraian tersebut dapat dipahami bahwa adat adalah salah satu buah dari budaya manusia, yang mencakup saling hubungan rasa dan akhlak manusia, utamnya saling hubungan manusia dengan sesamanya baik yang bersifat perseorangan, kelompok, golongan, suku, bangsa dan antar bangsa, termasuk silang hubungan manusia itu sendiri dengan tuhannya, makhluk lainnya dan alam lingkungannya. Karenanya, adat istiadat mencakup nilai-nilai ritual dan nilai-nilai sosial yang bersifat absolut dan relatif, yang berlaku sehari-hari dan yang sewaktu-waktu, yang tertulis dan tidak tertulis (Amirullah Syarbini, 2011).

Tradisi yang baik sering disebut sebagai kearifan lokal. Kearifan Lokal dilihat dari kamus Inggris Indonesia, terdiri dari 2 kata yaitu kearifan (wisdom) dan lokal (local). Local berarti setempat dan wisdom sama dengan kebijaksanaan. Dengan kata lain maka local wisdom dapat dipahami sebagai gagasan-gagasan, nilai-nilai, pandangan-pandangan setempat (local) yang bersifat bijaksana, penuh 
kearifan, bernilai baik, yang tertanam dan diikuti oleh anggota masyarakatnya. Secara konseptual, kearifan lokal dan keunggulan lokal merupakan kebijaksanaan manusia yang bersandar pada filosofi nilai-nilai, etika, cara-cara dan perilaku yang melembaga secara tradisional (S. Swarsi Geriya, 2007). Perilaku yang bersifat umum dan berlaku di masyarakat secara meluas, turun temurun, akan berkembang menjadi nilai-nilai yang dipegang teguh, yang selanjutnya disebut sebagai kebudayaan (budaya). Kearifan lokal didefinisikan sebagai kebenaran yang telah mentradisi atau ajeg dalam suatu daerah (Gobyah, 2003). Kearifan lokal atau sering disebut local wisdom dapat dipahami sebagai usaha manusia dengan menggunakan akal budinya (kognisi) untuk bertindak dan bersikap terhadap sesuatu, objek, atau peristiwa yang terjadi dalam ruang tertentu (Ridwan, N. A, 2007).

Kearifan (wisdom) secara etimologi berarti kemampuan seseorang dalam menggunakan akal pikirannya untuk menyikapi sesuatu kejadian, obyek atau situasi. Sedangkan lokal, menunjukkan ruang interaksi dimana peristiwa atau situasi tersebut terjadi. Dengan demikian, kearifan lokal secara substansial merupakan norma yang berlaku dalam suatu masyarakat yang diyakini kebenarannya dan menjadi acuan dalam bertindak dan berperilaku sehari-hari. Oleh karena itu, kearifan lokal merupakan entitas yang sangat menentukan harkat dan martabat manusia dalam komunitasnya (Geertz, 1992).

\section{Kerukunan Umat Beragama}

Sekarang ini umat beragama dihadapkan pada tantangan munculnya benturan-benturan atau konflik di antara mereka. Seperti konflik antar umat beragama di Poso, konflik di Sampit Palangkaraya Kalimantan Tengah dan sejumlah konflik horizontal lain yang terjadi dibeberapa wilayah di Indonesia yang mengatasnamakan agama. Potensi pecahnya konflik sangatlah besar, sebesar pemilahanpemilahan umat manusia ke dalam batas-batas objektif dan subjektif peradaban. Menurut Samuel P. Huntington, unsur-unsur pembatas objektif adalah bahasa, sejarah, agama, adat istiadat, dan lembagalembaga. Unsur pembatas subjektifnya adalah identifikasi dari 
manusia. Perbedaan antar pembatas itu adalah nyata dan penting ( ${ }^{1}$ Samuel P. Huntington, 1993).

Secara tidak sadar, manusia terkelompok ke dalam identitasidentitas yang membedakan antara satu dengan lainnya. Dari klasifikasi di atas, agama merupakan salah satu pembatas peradaban. Artinya, umat manusia terkelompok dalam agama Islam, Kristen, Katolik, Khong Hucu dan sebagainya. Potensi konflik antar mereka tidak bisa dihindari (Bassam Tibi, 1996).

Terdapat beberapa pemikiran diajukan orang untuk mencapai kerukunan dalam kehidupan beragama. Pertama, sinkretisme, yaitu pendapat yang menyatakan bahwa semua agama adalah sama. Kedua, reconception, yaitu menyelami dan meninjau kembali agama sendiri dalam konfrontasi dengan agama-agama lain. Ketiga, sintesis, yaitu menciptakan suatu agama baru yang elemen-elemennya diambilkan dari pelbagai agama, supaya dengan demikian tiap-tiap pemeluk agama merasa bahwa sebagian dari ajaran agamanya telah terambil dalam agama sintesis (campuran) itu. Keempat, penggantian, yaitu mengakui bahwa agamanya sendiri itulah yang benar, sedang agamaagama lain adalah salah; dan berusaha supaya orang-orang yang lain agama masuk dalam agamanya. Kelima, agree in disagreement (setuju dalam perbedaan), yaitu percaya bahwa agama yang dipeluk itulah agama yang paling baik, dan mempersilahkan orang lain untuk mempercayai bahwa agama yang dipeluknya adalah agama yang paling baik (A. Mukti Ali, 1992).

Multikulturalisme menjadi semacam respons kebijakan baru terhadap keragaman. Dengan kata lain, adanya komunitas-komunitas yang berbeda saja tidak cukup; sebab yang terpenting adalah bahwa komunitas-komunitas itu diperlakukan sama oleh negara. Oleh karena itu, multikulturalisme sebagai sebuah gerakan menuntut pengakuan (politics of recognition) (Charles Taylor, 1992) terhadap semua perbedaan sebagai entitas dalam masyarakat yang harus diterima, dihargai, dilindungi serta dijamin eksisitensinya. 


\section{Perspekrif Islam Terhadap Keberagaman}

Kita sadari bahwa, secara ideal tidak ada masalah dalam ketentuan normatif agama, semua berujung pada kebaikan universal, baik dalam relasi vertikal antara manusia dengan Allah (hablun minAllah), maupun dalam relasi horizontal sesama manusia (hablun minannas), baik di dunia maupun di akhirat kelak. Namun secara faktual, tidak jarang, agama justru menjadi dalih untuk memicu konflik, atau minimal menjadi sumber pembenaran atas berlangsungnya sengketa berdarah. Bahkan banyak sosiolog berpendapat, bahwa agama disamping berfungsi sebagai pemersatu, juga berfungsi sebagai pemecah belah, seperti mislanya faktor fanatisme agama yang menjadi pemicu terjadinya perang salib (yang banyak merugikan kedua belah pihak).

Namun dalam pandangan Islam perbedaan dianggap sebagai rahmat. Bahkan itu telah menjadi sunatullah. Dan Islam menghormati setiap agama dan kepercayaan manusia atau tanpa syarat apapun. Karena Agama merupakan kebutuhan ideal umat manusia. Manusia, tanpa agama, tidak dapat hidup sempurna. Manusia memerlukan agama bahkan merupakan fitrah dari kemanusian. Rasulullah bersabda:

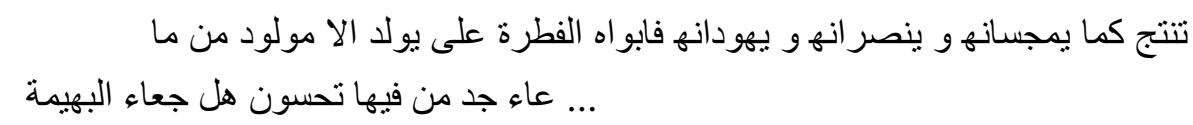

"Seorang bayi tak dilahirkan (ke dunia ini) melainkan ia berada dalam kesucian (fitrah). Kemudian kedua orang tuanyalah yg akan membuatnya menjadi Yahudi, Nasrani, ataupun Majusi -sebagaimana hewan yg dilahirkan dalam keadaan selamat tanpa cacat. Maka, apakah kalian merasakan adanya cacat? ... (HR. Muslim No. 4803)".

Dalam ajaran Al-Qurean sebagai pegangan umat Islam, banyak ditemukan ayat yang mendasari bagaimana seharusnya umat Islam berinteraksi baik dengan sesama agama, sesama agama lain, dan sesama manusia. Misalnya:

"Janganlah satu kaum (kumpulan lelaki) mengejek kaum (kumpulan lelaki) yang lain. Jangan pula (kumpulan 
perempuan) mengejek (kumpulan) perempuan yang lain, karena boleh jadi mereka (yang diejek) lebih baik dari pada mereka (yang mengejek) (QS. Al-Hujurat, 11).

Dalam surah lain juga Allah menjelaskan mengabarkan kepada manusia bahwasannya kewajiban bagi manusia untuk menghormati keragaman, sebagaimana firmannya,

"Wahai seluruh manusia, sesungguhnya Kami telah menciptakan kamu dari seorang lelaki dan seorang perempuan, dan Kami menjadikan kamu berbangsa-bangsa dan bersuku-suku, agar kamu saling mengenal. Sesungguhnya yang paling mulia di antara kamu di sisi Allah adalah yang paling bertaqwa. Sesungguhnya Allah Maha Mengetahui lagi Maha Mengenal (QS. Al-Hujurat, 13).

Ayat di atas menegaskan bahwa Allah mencipta manusia secara berbeda dengan berbagai macam ras, suku, laki-laki,dan perempuan tidak dimaksudkan agar mereka berjuang untuk menentang kehendak Allah dan melenyapkan semua perbedaannya sehingga menjadi identik, tetapi agar mereka menyadari akan kemahaagungan Tuhan melalui perbedaan-perbedaan itu dan berusaha mengetahui dan melengkapi satu sama lain (Sheikh Rashid Ghonoushi, 2007).

\section{METODOLOGI PENELITIAN}

Pada penelitian ini, menggunakan pendekatan Etnografi. Pendekatan etnografi merupakan pekerjaan mendeskripsikan suatu kebudayaan. Tujuan utama aktivitas ini adalah untuk memahami suatu kultur masyarakat setempat. Hal ini sesuai dengan pandangn Bronislaw Malisnowski dalam Spradley etnografi adalah "memahami sudut pandang penduduk asli, hubungannya dengan kehidupan untuk mendapatkan pandangannya mengenai dunia" (Spradley, James. P, 2007).

Riset ini dilakukan di Nggeru Kopa Desa Palama Dusun Kecamatan Donggo Kabupaten Bima. Adapun subyek dalam riset ini adalah pihak yang memahami tentang masalah yang diteliti, dan dianggap kompeten dibidangnya masing-masing, seperti: Kepala Dusun Nggeru Kopa dan Kepala Desa Palama, Pendeta dan da'i yang ada di Desa Palama Dusun Nggeru Kopa, Lembaga adat masyarakat Desa 
Palama Dusun Nggeru Kopa, Tokoh masyarakat di Desa Palama Dusun Nggeru Kopa, Tokoh Akademisi dan masyarakat yang berkompeten, Masyarakat setempat yang dianggap paham tentang budaya setempat

Teknik Pengumpulan Data dalam penelitian ini adalah observasi, wawancara, dokumentasi, tekhnik mencatat dan tekhnik rekaman. Sedangkan analisis data dalam penelitian ini adalah kualitatif, yang terdiri dari tiga komponen pokok yaitu pengumpulan data, reduksi data, sajian data, dan penarikan simpulan dan verifikasi (Sugiyono, 2011).

\section{HASIL TEMUAN}

\section{Ragam Kearifan Lokal Masyarakat Suku Donggo}

Kemajemukan bangsa ini, disatu sisi merupakan aset kekayaan khasanah budaya bangsa, namun disisi lain dapat menjadi potensi konflik tatkala tidak dapat dikelola dengan baik dan tidak memiliki sikap yang proposional terhadap kemajemukan ini. Kemajemukan yang memiliki potensi konflik tinggi dan sentral yaitu isu yang berkenaan dengan kemajemukan beragama. Agama merupakan isu yang sangat sentral dan cepat menimbulkan konflik dikalangan masyarakat (Agus Pahrudin, dkk, 2009).

Samuel Huntington dalam tesisnya yang berjudul The Cllass of Civilisation menyebut bahwa akan terjadi benturan peradaban akibat pertarungan ideologi (agama). Tesis tersebut menyatakan bahwa musuh besar bagi orang barat adalah Islam, atau sederhanya barat versus Islam. Agama islam dipandang sebagai parasait peradaban masa depan yang akan menebar teror dan konflik.

Meskipun tesis tersebut belum terbukti secara ilmiah atau masih bernuansa subyektif. Paling tidak, tesis tersebut sudah mulai nampak dalam dinamika geo politk islam dewasa ini. Namun dalam sketsa kehidupan sosial di daerah, tesis tersebut menjadi gugur dengan sendirinya. Eksistensi Islam justeru menjadi jalan tengah penyelesai masalah masyarakat yang memiliki latar belakang agama yang berbeda. Contoh keragaman budaya dan agama masyarakat donggo yang begitu rukun dan damai dalam kehidupan sosialnya terdapat di desa Mbawa dan Desa Palama dan Monggo. 
Sementara dari porsentasi penduduk yang ada di 3 (tiga) desa di sebuah kabupaten yang berada ujung timur pulau Sumbawa-NTB yakni Kabupaten Bima kecamatan donggo, sebagai berikut :

\begin{tabular}{|c|c|c|c|c|c|c|}
\hline \multirow[t]{2}{*}{ No } & \multirow[t]{2}{*}{ Desa \& Kecamatan } & \multicolumn{4}{|c|}{ Agama/Keyakinan } & \multirow[t]{2}{*}{ KK } \\
\hline & & $\begin{array}{l}\text { Islam } \\
(\%)\end{array}$ & $\begin{array}{l}\text { Katolik } \\
(\%)\end{array}$ & $\begin{array}{l}\text { Protestan } \\
(\%)\end{array}$ & $\begin{array}{l}\text { Lain- } \\
\text { lain }\end{array}$ & \\
\hline 1 & $\begin{array}{l}\text { Desa Mbawa/ Desa } \\
\text { Monggo } \\
\text { Tolonggeru/ }\end{array}$ & 18 & 55 & 2 & - & \\
\hline 2 & $\begin{array}{ll}\text { Desa Palama (Dusun } \\
\text { Nggeru Kopa) }\end{array}$ & 25 & 30 & 45 & - & \\
\hline
\end{tabular}

Sumber : Pemerintah Desa Palama dan Kepala Dusun Tolonggreu Desa MbawaMonggo dan berbagai responden dari 3 (tiga desa)

Menurut Wasiat (38) kepala dusun Tolongeru, dilihat dari porsentase jumlah penduduk dari ketiga dusun tersebut mayoritas beragama Katolik. Namun proses sosial kehidupan masyarakat berjalan dengan damai. Bahkan potret kehidupan mereka menjadi contoh bagi kerukukakan hidup untuk wilayah lain.

Bagi masyarakat Donggo (Dusun Nggeru Kopa, Dusun Tolonggeru dan desa Mbawa), keragaman budaya dan agama ini harus menjadi kemaslahatan bukan menjadi petaka bagi masyarakat desa mereka. Bagi ummat Muslim, memahami islam sebagai agama yang rahmatan lil 'alaminn. Sehingga islam merasa perlu mendefinisikan kehadirannya dalam konteks keragaman budaya dan agama, sekaligus menawarkan suatau harapan dan perspektif keagamaan yang baru bahwa islam adalah seraut wajah yang tersenyum smiling face of indonesian muslim, damai nir kekerasan (Roni Tabroni, dkk, 2006).

Faktor yang membentuk kekuatan sosial masyarakat Donggo, sejalan dengan apa yang dikatakan oleh George Riter, yang menyebut ada beberapa yang melatar belakangi perpaduan masyarakat; 
a. Adanya nilai-nilai budaya yang dibagi bersama

b. Yang dikembangkan menjadi norma-norma sosial dan

c. Dibatinkan oleh individu-individu menjadi motivasi-motivasinya (George Riter, 1992).

Selain karena pemahaman keagamaan yang benar, dalam sejarah peradaban masyarakat Donggo, kekuatan harmoni sosial masyarakat Donggo terwujud karena didukung oleh sejumlah kerarifan lokal yang sudah mengakar dalam kehidupan sosial mereka. Seperti budaya cepe kanefe, gtong royong, tio riana atau cama dan sejumlah koleksi' budaya lain sebagaimana yang disajikan pada bab sebelumnya, seperti budaya mbolo weki, kasama weki dan lain-lain.

2. Eksistensi Kearifan Lokal Dalam Mendukung Terwujudnya Kerukunan Ummat Beragama

\section{a. Budaya Cepe Kanefe (Perjodohan Dini)}

Peristiwa cepe kanefe ini di awali dengan 'kataki angi' (pesan) dimasa orak bayi, yang dilakukan oleh calon menantu, baik calon menantu yang laki-laki duluan atau yang perempuan duluan yang memesan (Ghazaly Ama La Nora, 2008). Ketika memesan salah satu orang tua bayi menyatakan pada orang tua bayi yang satu dengan melafalkan "anak ita/nggomi ake co'o pu ni manika labo ana nahu/mada" (anak bapak/ibu yang ini akan dijodohkan dengan anak saya).

Ketika permintaan itu disetujui oleh kedua orang tua belah pihak maka barulah dilakukan proses cempe kanefe antara kedua, kemudian dilanjutkan dengan sodi angi (tunangan) maka sejak itu cempe kanefe hingga diketahui oleh sara ro hukum (pemerintah dan adat) desa setempat (Ghazaly Ama La Nora, 2008).

Setelah sodi angi dilakukan, maka proses selanjutnya adalah ngge'e nuru (tinggal bersama) biasa dilakukan oleh calon pengantin pria yang sudah diketahui oleh sara do hukum di rumahnya calon penganti perempuan, dengan tujuan mengawinkan tabiat calon mempelai lelaki dan wanita sebelum mereka membangun rumah tangga, hal ini dilakukan antara satu tahun 
sampai lima belasan tahun, kemudian dilakukan rencana pernikahan.

Setelah terjadinya cempe kanefe, proses menunggu sampai anak-anak yang dijodohkan sejak dini tadi, hubungan keluarga dan kedekatan kedua kelurga bayi semakin erat, bahkan saling membantu dalam semua hal, terutama di bidang pertanian, dan setelah anak-anak tadi beranjak dewasa atau dalam posisi sebelum menikah mereka saling membantu pekerjaan kedua calon mertua masing-masing, jadi selama masa menunggu pernikahan sudah banyak yang dikorbankan oleh kedua belah pihak, terutama waktu dan tenaga.

Dampak dari cempe kanefe tadi adalah, menimbulkan perasaan tanggung jawab dari kedua belah pihak calon mempelai yakni ada amanah orang tua yang harus di wujudkan dan di jaga, dilestarikan, di bina dan dituruti, karena telah terikat dengan peristiwa sakral, mengenai jodoh atau tidak itu urusan Allah yang terpenting sudah berusaha menjaga dan membina sekuat mungkin.

Bila kedua calon masih melanjutkan sekolah misalnya sampai SMA bahkan sampai perguruan tinggi, maka selama itu kedua belah pihak harus saling menunggu, dan bila pihak laki-laki saja yang melanjutkan sekolah maka pihak orang tua perempuan harus ikut membantu membiayai sesuai dengan kesepakatan, begitupun seandainya calon laki-laki mencari pekerjaan maka pihak perempuan harus bisa ikut membantu biaya. Walau yang laki-laki sedang melanjutkan kepada pendidikan tinggi, nggee nuru tetap dilakukan ketika ia berlibur, sebagai bentuk pengabdian dan junjung tingggi cepe kanefe.

Ngge'e nuru biasanya dilakukan oleh calon pengantin lakilaki di rumah calon perempuan setelah menginjak usia remaja, peristiwa ini biasanya dilakukan satu sampai lima belas tahun sambil menunggu hari $\mathrm{H}$ pernikahan baik yang menlanjutkan sekolah maupun yang tidak melanjutkan sekolah, ngge'e nuru bukan jangok atau budak, namun bertujuan untuk beradaptasinya calon pengantin laki-laki pada keluarga calon pengantin 
perempuan, dengan tujuan menguji kesabaran, menyatukan tabiat dan sifat kedua keluarga, sang laki-laki harus mampu menyesuaikan diri dengan keluarga wanita, dengan ikut membantu mengerjakan bidang pertanian, kebutuhan rumah tangga, dan juga untuk melihat etiket (sopan santun) dan etikanya selama ngge'e nuru.

Ketika sang laki-laki mendapatkan pekerjaan lalu keluarga laki-laki tidak menepati kesepakatan awal atau sebaliknya keluarga sang perempuan tidak sabar menunggu yang laki mencari pekejaan atau menyelesaikan pendidikan.

Maka disinilah kemudian aspek hukum dari peristiwa sakral ini, apa lagi peristiwa sakral tadi mulai dari kataki angi, cempe kanefe hingga ngge'e nuru yang dari awal melibatkan sara ro hukum (adat dan hukum). Maka salah satu pihak yang merasa dirugikan harus mengadu kepada tokoh adat untuk diproses, lalu tokoh adat menggali semua informasi dari pengadu.

Tradisi ini sudah dipraktekkan masyarakat Donggo sejak lama dari turun temurun, tujuannya untuk merekatkan hubungan kekeluargaan sesama masyarakat Donggo, dengan adanya tradisi ini juga membuat masyarakat Donggo sangat solid dalam segala hal.

Tradisi ini memiliki segi-segi hukum, kenapa dikatakan memiliki segi hukum, karena kalau hukum kita maknai sebagai satu system yang ditati atau disepakati oleh komunitasnya dan memiliki sanksi maka, ia sudah menjadi sutu hakum bagi masyarakatnya. Begitupun kacampokanefe, ia ditegakkan lewat hukuman sosial dan hukuman materil (fisik) dengan sanksi membayar denda, dan sanksi atau denda itu ditegakkan oleh komunitas adat Donggo sejak dari dulu kala. Adapun proses hukum atau dendanya dilakukan bila salah satu pihak, baik perempuan maupun sang calon mempelai laki-kaki mengkhiati kesepakatan yang sudah terjadi sejak bayi dulu. Biasanya pelaksanaan proses pemberian ganti rugi bisa berangkat atas dasar kesadaran langsung pihak yang membangkang dari kesepakatan 
dan bisa juga dilakukan lewat lembaga adat, mengenai besaran dendanya adalah sangat tergatung dari situasi dan kondisi perekonomian yang melakukan pengingkaran janji atau kesepakatan.

Sayang akhir-akhir ini tradisi hukum cempe kanefe itu semakin pudar disebabakan oleh pengaruh tingkat Pedidikan yang semakin merata dan tinggi, kemudian semakin terbukanya masyarakat tersebut lewat pengaruh media, pergaulan dan faktorfaktor luar lainnya.

\section{b. Perkawinan Silang}

Perkawinan memang sampai saat ini masih menyimpan berbagai kasus-kasus baru yang titik temunya tidak mudah untuk ditemukan. Kawin beda agama adalah salah satunya, tentu masyarakat awam atau orang yang berpenduduk dalam sebuah tempat penganut agama yang kuat jarang mendengar kasus ini.

Namun, perkawinan yang seperti ini tidak jarang kita temukan di kota metropolitan atau kota-kota maju yang lain. Kawin beda agama merupakan perkawinan yang dilakukan antara sepasang manusia, namun mereka menganut sebuah keyakinan atau agama yang berbeda. Ini menjadi sebuah kasus yang rumit disebabkan bahwa aturan-aturan yang berlaku di Indonesia, mulai dari Undang-undang, agama, dan adat tidak secara pasti dan bahkan menolak tentang perkawinan semacam ini.

Model perkawinan silang atau nikah beda agama pada mayarakat Dusun Nggeru Kopa dan Tolonggeru adalah kedua pasangan sebelum menyelenggarakan pernikahan sah, wajib hukumnya salah seorang diantar mereka untuk meninggalkan agamanya tanpa paksaan, kemudian harus memilih pindah agama calon istri atau calon suaminya. Jadi tidak boleh mempertahankan agama yang berbeda.

Kejadian ini biasanya tidak mempengaruhi hubungan kedua pihak keluarga. Masyarakat setempat selalu memahi secara dewasa, justeru hasil dari perkawinan silang ini akan melahirkan kekuatan kekeluargaan yang cukup erat. Sehingga dalam pespektif 
islam maupun agama lain pernikahan tersebut adalah pernikahan yang sah.

\section{Kekuatan Budaya Lokal}

Selain faktor perkawinan silang yang memperkuat kerukunan suku Donggo, faktor yang berperan dalam mewujudkan keharmonisan di 3 desa tersebut adalah faktor budaya. Masyarakat dikenal sebagai suku atau komunitas masyarakat yang memiliki kekuatan dan ketahan sosial yang cukup baik. Salah satu yang membuat mereka adalah budaya nikah sesama suku Donggo. Hampir jarang ditemui orang donggo yang menikah dengan orang di luar dari suku Donggo, belum lagi budaya lain yang makin merekat kekeluaragaan mereka

Menurut Romo Wayan (34) pemuka Katolik Dusun Tolonggreu, bahwa budayalah yang membuat kebersamaan ditempat tersebut yang mengikat satu sama lain. Diakuinya faktor yang paling berperan terwujudnya kerukunan masuyarakat Donggo adalah budaya, seperti nikah sesama suku. Kalau peran pemerintah tidak begitu terlalu. Sebab masalahnya tidak ada hal yang perlu dipertentangkan. Menurutnya, yang menyatukan mereka adalah gotong ronyong yang sudah mengakar sejak nenek moyang. Bahkan lebaran dan ulang tahun gereja semua ikut memeriahkannya (Romo Agustinus Wayan Yuliayanto, 2014).

Dalam urusan pernikahan, gotong rumah, sunatan, dan lainlain dalam persoalan keagamaan selalu dilakukan secara besama. Bahkan menurut pengakuan guru KTKIS Gereka Katolik bahwa ummat Katolik pernah menjadi panitia MTQ di dusun Nggeru Kopa. Artinya bahwa kebersamaan dan budaya menjadi hal nomor satu yang harus junjung tinggi. Serta saling menghormati keyakinan satu sama lain menjadi sebuah hukum yang tidak tertulis yang ada dalam kehidupan masyarakat Donggo.

Ajaran Islam juga menganjurkan manusia untuk bekerja sama dan tolong menolong (ta'awun) dengan sesama manusia dalam hal kebaikan. Dalam kehidupan sosial kemasyarakatan umat Islam dapat berhubungan dengan siapa saja tanpa batasan ras, bangsa, dan agama. 
Memahami dan mengaplikasikan ajaran Islam dalam kehidupan masyarakat tidak selalu hanya dapat diharapkan dalam kalangan masyarakat muslim. Islam dapat diaplikasikan dalam masyarakat manapun, sebab secara esensial ia merupakan nilai yang bersifat universal. Kendatipun dapat dipahami bahwa Isalam yang hakiki hanya dirujukkan kepada konsep al-quran dan As-sunnah, tetapi dampak sosial yanag lahirdari pelaksanaan ajaran isalam secara konsekwen dapat dirasakan oleh manusia secara keseluruhan.

Hubungan antara muslim dengan penganut agama lain tidak dilarang oleh syariat Islam, kecuali bekerja sama dalam persoalan aqidah dan ibadah. Kedua persoalan tersebut merupakan hak intern umat Islam yang tidak boleh dicampuri pihak lain, tetapi aspek sosial kemasyarakatan dapat bersatu dalam kerja sama yang baik. Kerja sama antar umat bergama merupakan bagian dari hubungan sosial anatar manusia yang tidak dilarang dalam ajaran Islam. Hubungan dan kerja sama dalam bidang-bidang ekonomi, politik, maupun budaya tidak dilarang, bahkan dianjurkan sepanjang berada dalam ruang lingkup kebaikan.

\section{SIMPULAN}

Mencermati sajian dari pembahasan riset di atas, maka peneliti dapat menyimpulkan beberapa point antara lain; Pertama, kearifan lokal yang ada Suku Donggo Kabupaten Bima meliputi cepe kanefe, doa jama, tio riana atau cama, perkawinan silang dan tradisi nikah sesama keluarga sendiri dan pantang menikah orang luar. Sederat kearifan lokal yang tersebut merupakan khasanah kolekasi budaya yang dimiliki oleh masyarakat tersebut. Kedua, Kearifan lokal yang dimiliki oleh masyarakat Donggo merupakan aspek yang paling berperan dalam mewujudkan kerukunan ummat beragama pada masyarakat di dusun Nggeru Kopa desa Palama Kabupaten Bima. Keberadaan lembaga pemerintah seperti kepolisian, TNI atau peran pemerintah secara umum tidak begitu siginifikan dalam proses pembentukan budaya damai dan stablitas sosial di dusun tersebut. Meskipun peneliti belum bisa menyajikan data yang cukup, bahwa daerah yang paling rendah tingkat kriminalitas dan pelanggaran hukum berada di kecamatan Donggo. 
DAFTAR PUSTAKA

Ahmad Asroni, "Membendung Radikalisme Islam: Upaya Merajut Kerukunan Antar Umat Beragama”, dalam Erlangga Husada, dkk., Kajian Islam Kontemporer (Jakarta: Lembaga Penelitian UIN Syarif Hidayatullah, 2007),

Martin Van Bruinessen, "Genealogies of Islamic Radicalism in postSuharto Indonesia", Southeast Asia Research no 2, 2002,

Hairus Salim dan Suhadi, "Membangun Wibawah dari Bawah, (Yogyakarta: LKiS, 2007),

Sudarwan Danim, "Agenda Pembaharuan Sistem Pendidikan, (Yogyakarta:Pustaka Pelajar, Cetakan -II)

George Ritzer, Sosiologi Ilmu Pengetahuan Perparadigma Ganda, tej. Alimandan (Jakarta: Rajawali Pers, 1992,

Amirullah Syarbini. Islam dan Kearifan Lokal. Makalah yang dipresentasikan pada The 11TH Annual Conference on Islamic Studies. Bangka Belitung, 10-13 Oktober 2011)

Ridwan, N. A. (2007) 'Landasan Keilmuan Kearifan Lokal', IBDA, Vol. 5, No. 1, Jan-Juni 2007, hal 27-38, P3M STAIN, Purwokerto.

Samuel P. Huntington, "Benturan Antar Peradaban, Masa Depan Politik Dunia?” dalam (Jurnal Ulumul Qur'an, No. 5, Vol.IV, 1993)

Bassam Tibi, "Moralitas Internasional sebagai Landasan Lintas Budaya”, dalam M. Nasir Tamara dan Elza Pelda Taher (ed.), Agama dan Dialog Antar Peradaban, (Jakarta: Yayasan Paramadina, 1996)

A. Mukti Ali, "Ilmu Perbandingan Agama, Dialog, Dakwah dan Misi", dalam Burhanuddin Daja dan Herman Leonard Beck (red.), Ilmu Perbandingan agama di Indonesia dan Belanda, (Jakarta : INIS,

Sugiyono, "Metode Penelitian Pendidikan", (Bandung: Alfabeta, Edisi $\mathrm{Ke}-13,2011)$

Spradley, James. P. "Metode Etnografi. Edisi Kedua; (Yogyakarta: TIARA WACANA, 2007)

Agus Pahrudin,dkk. Harmonisasi Agama dan Budaya di Indonesia, Balai Penelitian dan pengembangan Agama jilid 12009

Roni Tabroni, dkk. Menggagas kesalehan Multikultural di Jawa Barat, Bandung, 2006

Ghazaly Ama La Nora, Mutiara Donggo: Biografi Perjuangan Tuan Guru Abdul Majid Bakry, Jakarta Barat: NCI Press, 2008, hlm, 263.

Sheikh Rashid Ghonoushi, "Pluralisme dan Monoteisme dalam Islam, dalam Mansoor Al-Jamri dan Abduwahab El-Affendi (ed.), (2007), Islamisme, Pluralisme dan Cicil Society, ter. Machnun Husein, Yogyakarta: Tiara Wacana 